\title{
Potensi Rumput Laut Eucheuma sp. Terhadap Kepadatan Fitoplankton Chlorella sp.
}

\author{
Ria Azizah $^{1 *}$, Indrihastuti Sulistianingtiyas ${ }^{2}$, Delianis Pringgenies ${ }^{1}$ dan Siti Rudiyanti² \\ IJurusan Ilmu Kelautan, Fakultas Perikanan dan Ilmu Kelautan, Universitas Diponegoro \\ 2Jurusan Perikanan, Fakultas Perikanan dan IImu Kelautan, Universitas Diponegoro \\ JI. Prof. Soedarto, SH. Kampus UNDIP Tembalang, Semarang 50275 \\ Email : riaazizahtn@yahoo.co.id
}

\begin{abstract}
Abstrak
Chlorella sp. merupakan sumber makanan bagi ikan dan udang. Untuk menumbuhkan, Chlorella sp. maka diperlukan media kultur dengan nutrien yang baik. Eucheuma sp. merupakan rumput laut yang mengandung mineral - mineral yang bermanfaat bagi pertumbuhan Chlorella sp. Pemberian ekstrak Eucheuma sp. diharapkan dapat mendukung pertumbuhan Chlorella sp. Tujuan dilakukan penelitian untuk mengetahui pengaruh ekstrak Eucheuma sp. terhadap kepadatan Chlorella sp. dan konsentrasi terbaik dari ekstrak Eucheuma sp. yang menghasilkan kepadatan Chlorella sp. yang tertinggi. Penelitian ini dilaksanakan pada bulan Januari - Maret 2005 di Laboratorium Bioteknologi dan Eksplorasi Laut, Teluk Awur, UNDIP, Jepara dan Laboratorium Jurusan Perikanan, UNDIP, Semarang. Materi yang digunakan yaitu ekstrak Eucheuma sp., Chlorella sp. dan media kultur. Metode yang digunakan adalah eksperimental laboratories. Konsentrasi ekstrak Eucheuma sp. yang digunakan adalah: A (10 mg/L); B (100 mg/L); C (200 mg/L); D (300 $\mathrm{mg} / \mathrm{L}) ; \quad E(400 \mathrm{mg} / \mathrm{L}) ; \mathrm{F}(500 \mathrm{mg} / \mathrm{L}) ; \mathrm{G}$ ( tanpa pemberian ekstrak Eucheuma sp.). Hasil penelitian menunjukkan perlakuan D (300 mg/L) menghasilkan kepadatan Chlorella sp. tertinggi pada puncak populasi, yaitu 6,293 log sel/mL dan pada akhir populasi, yaitu 6,012 log sel/mL dengan konstanta pertumbuhan spesifik sebesar 0,161.
\end{abstract}

Kata kunci: Kepadatan, Chlorella, Eucheuma

\begin{abstract}
Chlorella sp. is the source of food to prawn and fish. In order to grow Chlorella sp. so need a culture media with a good nutrient. Eucheuma sp. is a seaweed it cantains benefit minerals for the growth of Chlorella sp. The giving of Eucheuma sp. it is to be hoped to support the the growth of Chlorella sp. This research is aimed to know the effect of Eucheuma sp. extract to density of Chlorella sp. and the best concentration of Eucheuma sp. extract produce the highest density of Chlorella sp. This research was conducted in January - March 2005 at the Laboratory of Biotechnology and Marine Exploration, Teluk Awur, UNDIP, Jepara and Laboratory of Fisheries Department UNDIP, Semarang. Materials used in this research consisted of Eucheuma sp. extract, Chlorella sp. and culture media. This research method used experimental laboratories. The concentration that used in this research : A (10 mg/L); B (100 mg/L); C (200 mg/L); D (300 mg/L); E (400 mg/L); F (500 mg/L); G (without giving extract of Eucheuma sp.). The result of this research showed that the $D$ treatment produce the highest Chlorella sp. density at peak of population, that is $6,293 \mathrm{log} \mathrm{sel} / \mathrm{mL}$ and the end of population that is $6,012 \mathrm{log}$ sel/mL with specific growth rate 0,161 .
\end{abstract}

Keyword: Density, Chlorella., Eucheuma

\section{PENDAHULUAN}

Fitoplankton merupakan produser primer pada rantai makanan suatu ekosistem perairan, yang berperan sebagai makanan alami. Fitoplankton juga berperan sebagai penyangga kualitas air sekaligus memiliki kemampuan meningkatkan kandungan oksigen terlarut melalui proses fotosintesis. Adiwijaya et. al, 
(1996) menambahkan bahwa fitoplankton juga berperan sebagai stabilisator dalam ekosistem perairan karena kemampuannya mengatasi fluktuasi parameter kualitas air, seperti suhu dan $\mathrm{pH}$.

Chlorella sp. adalah salah satu jenis fitoplankton yang digunakan sebagai sumber makanan alami. Pertumbuhan Chlorella sp. dipengaruhi oleh nutriennutrien, seperti nitrogen, phospat serta unsur-unsur lain yang terkandung dalam media pemeliharaan. Dalam pertumbuhannya, Chlorella sp. membutuhkan media pemeliharaan yang tidak terkontaminasi organisme lain yang bersifat pengganggu.

Eucheuma sp. merupakan rumput laut yang memiliki kandungan nitrogen yang tinggi serta unsur - unsur lain, yaitu kalium, klor, magnesium, kalsium, natrium, belerang, dan yodium (Winarno, 1990).

Selain memiliki kandungan gizi yang tinggi, Eucheuma sp. juga berpotensi sebagai antibakteri. Hal ini sudah dibuktikan pada hasil penelitian awal yang menunjukkan ekstrak Eucheuma sp. dapat menghambat pertumbuhan bakteri patogen, yaitu Vibrio sp. dan Bacillus sp. (Ekasari, 2004).

Informasi tentang rumput laut Eucheuma sp. juga fitoplankton Chlorella sp. telah banyak dilakukan. Namun penelitian mengenai peranan rumput laut Eucheuma sp. terhadap kepadatan fitoplankton Chlorella sp. belum banyak dilakukan.

Kandungan mineral yang terdapat pada Eucheuma sp. berperan penting dalam proses pertumbuhan Chlorella sp. Pemberian ekstrak Eucheuma sp. diharapkan dapat meningkatkan pertumbuhan Chlorella sp. Pola pertumbuhan Chlorella sp. dapat dilihat dari kepadatan sel Chlorella sp. pada puncak populasi dan kepadatan sel Chlorella sp. pada akhir populasi. Selain itu dilakukan penghitungan konstanta pertumbuhan spesifik Chlorella sp. Penghitungan konstanta pertumbuhan spesifik berguna untuk mengetahui konsentrasi terbaik dari ekstrak Eucheuma sp. yang menghasilkan kepadatan Chlorella sp. yang optimal.

Faktor lain yang berpengaruh terhadap pertumbuhan Chlorella sp. adalah suhu, $\mathrm{pH}$, oksigen terlarut, dan salinitas. Tujuan dilakukannya pengukuran parameter kualitas air adalah untuk melihat seberapa besar dampak ekstrak Eucheuma sp. terhadap air media. Selanjutnya dapat diketahui dampak air media tersebut terhadap pertumbuhan Chlorella sp. Berdasarkan hal tersebut, maka tujuan dari penelitian adalah untuk mengetahui pengaruh ekstrak rumput laut Eucheuma sp. terhadap kepadatan Chlorella sp. dan mengetahui konsentrasi terbaik dari ekstrak rumput laut Eucheuma $s p$. yang menghasilkan kepadatan tertinggi Chlorella sp.

\section{MATERI DAN METODE}

Penelitian menggunakan rancangan percobaan Rancangan Acak Lengkap (RAL) dimana 6 perlakuan mendapatkan ekstrak Eucheuma sp. dengan konsentrasi yang berbeda, yaitu : A (10 mg/L); B (100 $\mathrm{mg} / \mathrm{L}) ; C(200 \mathrm{mg} / \mathrm{L}) ; \quad D(300 \mathrm{mg} / \mathrm{L}) ; \mathrm{E}(400$ $\mathrm{mg} / \mathrm{L}) ; \mathrm{F}(500 \mathrm{mg} / \mathrm{L})$ dan 1 perlakuan kontrol G ( $0 \mathrm{mg} / \mathrm{L}$ ). Pada setiap perlakuan dilakukan 3 kali ulangan. Hipotesis yang diajukan untuk mengambil keputusan sesuai dengan tujuan adalah sebagai berikut:

Ho: Pemberian ekstrak Eucheuma sp. dengan konsentrasi berbeda tidak menyebabkan kepadatan sel Chlorella sp. yang berbeda

$\mathrm{H}_{1}$ : Pemberian ekstrak Eucheuma sp. dengan konsentrasi berbeda memberikan kepadatan sel Chlorella sp. yang berbeda.

Kaidah pengambilan keputusan dengan uji F dari hipotesis tersebut sebagai berikut:

F hitung:

$\leq$ Ftabel, maka terima $\mathrm{H}_{0}$ dan tolak $\mathrm{H}_{1}$

$>$ Ftabel, maka tolak $\mathrm{H}_{0}$ dan terima $\mathrm{H}_{1}$

Materi penelitian yang digunakan adalah ekstrak rumput laut Eucheuma sp., dan fitoplankton Chlorella sp., serta air 

sebagai medianya. Chlorella sp. didapatkan dari hasil kultur murni yang tidak tercampur oleh organisme lain yang dikoleksi dari Laboratorium Makanan Alami, Balai Besar Pengembangan Budidaya Air Payau (BBPBAP) Jepara. Chlorella sp. yang dikoleksi ditempatkan pada erlenmeyer volume $500 \mathrm{~mL}$ dengan kepadatan 100.000 $\mathrm{sel} / \mathrm{mL}$. Rumput laut Eucheuma sp. seberat $1 \mathrm{~kg}$ dikoleksi dari Pantai Bandengan, Jepara. Air media yang digunakan adalah air laut steril dengan salinitas $28 \%$ \%o.

\section{Persiapan peralatan}

Sebelum dilakukan penelitian, peralatan yang akan digunakan disterilisasi dengan klorin. Sterilisasi dilaksanakan untuk membersihkan mikroorganisme sehingga peralatan yang akan digunakan dalam penelitian bersih. Untuk menghilangkan sisa-sisa klorin, peralatan dinetralkan menggunakan natrium thiosulfat hingga bau klorin hilang. Sterilisasi model ini umumnya digunakan untuk mensterilkan alat-alat dan botol ukur yang terbuat dari gelas (Isnansetyo dan Kurniastuty, 1995).

\section{Penentuan volume sel Chlorella sp.}

Menurut Martosudarmo dan Sabarudin (1983), untuk menghitung volume sel Chlorella sp. yang dibutuhkan, digunakan rumus sebagai berikut :

$$
V_{1}=\frac{N_{2} x V_{2}}{N_{1}}
$$

Keterangan :

$V_{1}=$ Volume Chlorella sp. yang digunakan untuk penebaran awal (mL)

$\mathrm{V}_{2}=$ Volume air media yang akan ditebar bibit $(\mathrm{mL})$

$\mathrm{N}_{1}=$ Jumlah stok Chlorella sp. (sel $/ \mathrm{mL}$ ).

$\mathrm{N}_{2}=$ Jumlah Chlorella sp. yang dikehendaki (sel/mL)

\section{Pembuatan larutan ekstrak Eucheuma sp.}

Penelitian ini menggunakan bahan uji berupa ekstrak Eucheuma sp. yang merupakan hasil ekstraksi dari rumput laut Eucheuma sp. Ekstrak Eucheuma sp. yang akan digunakan terlebih dahulu dilarutkan dalam air. Menurut Wahyuni (1988), pembuatan larutan dari ekstrak Eucheuma sp menggunakan rumus sebagai berikut :

$$
Q=\frac{V \times K}{P}
$$

Keterangan :

$Q=$ Berat bahan yang akan dilarutkan (mg)

$\mathrm{V}=$ Volume pelarut $(\mathrm{mL})$

$\mathrm{P}=$ Volume dosis penggunaan $(\mathrm{mL})$

$\mathrm{K}=$ Konsentrasi ekstrak Eucheuma sp. yang dikehandaki (mg/L)

\section{Persiapan air media}

Air media yang digunakan dalam penelitian ini adalah air laut yang steril. Menurut Isnansetyo dan Kurniastuti (1995), air laut yang akan digunakan terlebih dahulu disaring, lalu disterilkan dengan klorin sebanyak $60 \mathrm{mg} / \mathrm{L}$ selama minimal 1 jam. Untuk menghilangkan sisa - sisa klorin dalam air laut, dilakukan penetralan air laut menggunakan natrium thiosulfat sebanyak $20 \mathrm{mg} / \mathrm{L}$. Penetralan dilakukan hingga bau klorin hilang. Pada penelitian ini digunakan media pemeliharaan Walne Isnansetyo dan Kurniastuty (1995)

\section{Ekstraksi rumput laut}

Sampel rumput laut Eucheuma sp. seberat $1 \mathrm{~kg}$ yang dikoleksi dari Pantai Bandengan, Jepara langsung dibawa ke Laboratorium Bioteknologi dan Eksplorasi Laut, Kampus Teluk Awur, UNDIP, Jepara untuk diekstraksi. Sebelum diekstraksi rumput laut terlebih dahulu dibersihkan menggunakan air untuk menghilangkan garam dan parasit yang menempel. Menurut Taylor dan Zheng (1995) dalam Ekasari (2004) setelah dibersihkan, rumput laut diblender kemudian direndam dalam larutan metanol selama 24 jam. Rumput laut yang sudah direndam kemudian disaring dengan kertas saring. Larutan hasil penyaringan kemudian diuapkan dengan rotavapour pada suhu $30^{\circ} \mathrm{C}-40^{\circ} \mathrm{C}$.

Proses ekstraksi berlangsung sampai didapatkan ekstrak Eucheuma sp. dalam bentuk pasta. Penghancuran rumput laut dengan blender bertujuan untuk mempermudah proses penyerapan 

senyawa bioaktif ke dalam larutan metanol. Perendaman menggunakan metanol bertujuan untuk menyerap senyawa bioaktif yang terdapat pada rumput laut. (Winarno, 1990).

\section{Penelitian pendahuluan}

Penelitian pendahuluan ini dimaksudkan untuk mencari kisaran konsentrasi ekstrak Eucheuma sp. yang akan digunakan sebagai dasar pemberian perlakuan pada penelitian utama. Berdasarkan basis angka 10 deret logaritmik maka konsentrasi ekstrak Eucheuma sp. adalah $0 ; 0,001 ; 0,01 ; 0,1 ; 1$; $10 ; 100 \mathrm{mg} / \mathrm{L}$.

Pada penentuan ambang apabila dengan deret konsentrasi bahan uji 0 ; 0,$001 ; 0,01 ; 0,1 ; 1 ; 10 ; 100 \mathrm{mg} / \mathrm{L}$ tidak diperoleh batas konsentrasi maksimum pemberian ekstrak Eucheuma sp., maka uji dilanjutkan dengan menambahkan 2 perlakukan dengan konsentrasi ekstrak Eucheuma sp. 500 dan 1000 mg/L.

\section{Penelitian utama}

Hasil penelitian pendahuluan digunakan sebagai acuan dalam melakukan penelitian utama. Perlakuan konsentrasi ekstrak Eucheuma sp. yang ditetapkan dalam penelitian utama didapat dari hasil peninjauan kisaran kepadatan Chlorella sp. pada konsentrasi ekstrak Eucheuma sp. yaitu antara konsentrasi 0,001 sampai konsentrasi 1000 $\mathrm{mg} / \mathrm{L}$. Dari penelitian pendahuluan diamati bagaimana kepadatan Chlorella sp. pada masing-masing pemberian konsentrasi ekstrak Eucheuma sp.

Konsentrasi ekstrak Eucheuma sp. yang akan digunakan untuk penelitian utama adalah A (10 mg/L); B (100 mg/L); C $(200 \mathrm{mg} / \mathrm{L}) ; \mathrm{D}(300 \mathrm{mg} / \mathrm{L}) ; \mathrm{E}(400 \mathrm{mg} / \mathrm{L}) ; \mathrm{F}$ (500 mg/L) ditambah satu perlakuan tanpa pemberian ekstrak Eucheuma sp. ( $G$ ) yang akan dijadikan kontrol pada penelitian utama.

Pada setiap perlakuan dilakukan 3 kali ulangan. Pengamatan terhadap kepadatan Chlorella sp. dilakukan dengan pengambilan sampel setiap 24 jam sekali selama 12 hari. Pengambilan sampel selama 12 hari berdasarkan asumsi bahwa selama kurun waktu tersebut Chlorella sp. telah melalui seluruh rangkaian fase pertumbuhannya (Sachlan, 1984).

Setiap hari dilakukan pengambilan sampel dengan volume $5 \mathrm{~mL}$ dan diberi 4 tetes formalin $4 \%$ yang bertujuan untuk menghambat pertumbuhan Chlorella sp. sehingga memudahkan dalam pengamatan dengan mikroskop (Haryanto, 2003). Parameter lain yang diamati adalah suhu air, salinitas, pH, dan oksigen terlarut.

\section{Penghitungan kepadatan Chlorella sp.}

Kepadatan sel Chlorella sp. diamati dengan menggunakan alat haemocytometer. Sebelum dimulai penghitungan, haemocytometer dibersihkan dengan air aquades kemudian dikeringkan dengan kertas tissue. Sampel Chlorella sp. dikoleksi dengan pipet dan diteteskan pada haemocytometer yaitu di parit yang melintang, kemudian dipasang gelas penutup haemocytometer. Dalam hal ini, harus memperhatikan posisi gelas penutup agar tidak timbul gelembung udara. Luas permukaan bergaris pada haemocytometer $=1 \mathrm{~mm}^{2}$ dan kedalamannya $=0,1 \mathrm{~mm}$, maka volume sampel diatas permukaan bergaris $=1 \mathrm{~mm}^{2}$ $x 0,1 \mathrm{~mm}=0,1 \mathrm{~mm}^{3}$ atau $0,0001 \mathrm{~cm}^{3}$ atau $0,0001 \mathrm{~mL}$. Misalkan jumlah sel adalah N, berarti dalam $0,1 \mathrm{~mm}^{3}$ terdapat $\mathrm{N}$ sel. Jadi dalam $1 \mathrm{~cm}^{3}$ atau $1 \mathrm{~mL}$ jumlah Chlorella sp. adalah $\mathrm{N} \times 10^{4}$ (Mujiman, 2000).

\section{Penghitungan konstanta pertumbuhan spesifik}

Konstanta pertumbuhan spesifik Chlorella sp. dihitung menggunakan rumus Fogg (1979) dalam Sosiawan (2004) sebagai berikut :

$$
K=\frac{\log w t-\log w 0}{t}
$$

Keterangan :

$\mathrm{K}$ : Konstanta pertumbuhan spesifik

$\mathrm{W}_{+}$: Jumlah populasi pada hari ke- $\dagger$

wo: Jumlah populasi pada hari ke-0

t : Waktu 


\section{Analisis Data}

Data - data yang diperoleh selama penelitian dianalisis secara statistik. Data data tersebut terlebih dahulu diuji kenormalan ragamnya dengan uji normalitas Lilieffors (Sudjana, 1986). Disamping pengujian terhadap normal tidaknya distribusi data, diperlukan pengujian terhadap kesamaan (homogenitas) data atau uji Bartlet (Arikunto, 1998).

Setelah itu dianalisis dengan uji $\mathrm{F}$ dengan taraf uji $5 \%$ dan $1 \%$. Untuk mengetahui pengaruh antar perlakuan, dilakukan uji ganda Duncan pada taraf uji $5 \%$ dan $1 \%$ untuk mengetahui perlakuan mana yang berbeda (Steel and Torrie (1960) dalam Srigandono (1989)).

\section{HASIL DAN PEMBAHASAN}

\section{Penelitian pendahuluan}

Pada penelitian pendahuluan mengenai Pengaruh Ekstrak Eucheuma sp. Terhadap Kepadatan Chlorella sp. ini digunakan 9 perlakuan, yaitu A lekstrak Eucheuma sp. 0,001 mg/L); B (ekstrak Eucheuma sp.0,01 mg/L); C (ekstrak Eucheuma sp.0,1 mg/L); D (ekstrak Eucheuma sp. $1 \mathrm{mg} / \mathrm{L}$ ); $\mathrm{E}$ (ekstrak
Eucheuma sp. $10 \mathrm{mg} / \mathrm{L}$ ); $\mathrm{F}$ (ekstrak Eucheuma sp. $100 \mathrm{mg} / \mathrm{L}$ ); $\mathrm{G}$ (ekstrak Eucheuma sp. $500 \mathrm{mg} / \mathrm{L}$ ); $\mathrm{H}$ (ekstrak Eucheuma sp. $1000 \mathrm{mg} / \mathrm{L}$ ); I (tanpa pemberian ekstrak Eucheuma sp.) dengan hasil kepadatan Chlorella sp. terlihat pada tabel 1. Kepadatan Chlorella sp. pada penelitian pendahuluan tertera pada Gambar 2 .

Pada semua perlakuan, yaitu yang diberi ekstrak Eucheuma sp. maupun yang tidak diberi ekstrak Eucheuma sp. (kontrol) mengalami peningkatan kepadatan Chlorella sp. yang seirama hingga mencapai puncaknya (hari ke- 5), setelah melewati hari ke- 5, kepadatan Chlorella sp. mengalami penurunan (Tabel 1).

Kepadatan Chlorella sp. pada puncaknya di hari ke-5 dari yang tertinggi sampai terendah berturut-turut adalah perlakuan $\mathrm{F}(100 \mathrm{mg} / \mathrm{L})$ yaitu $162 \times 10^{4}$ $\mathrm{sel} / \mathrm{mL}$; perlakuan E (10 mg/L) yaitu $145 \mathrm{x}$ $10^{4} \mathrm{sel} / \mathrm{mL}$; perlakuan D (1 mg/L) yaitu $111 \mathrm{x}$ $10^{4} \mathrm{sel} / \mathrm{mL}$; perlakuan $C(0,1 \mathrm{mg} / \mathrm{L})$ yaitu 93 $\times 10^{4} \mathrm{sel} / \mathrm{mL}$; perlakuan B $(0,01 \mathrm{mg} / \mathrm{L})$ yaitu $75 \times 10^{4} \mathrm{sel} / \mathrm{mL}$; perlakuan I (tanpa pemberian ekstrak Eucheuma sp.) yaitu 63 $\times 10^{4} \mathrm{sel} / \mathrm{mL}$; perlakuan A $(0,001 \mathrm{mg} / \mathrm{L})$ yaitu $42 \times 10^{4} \mathrm{sel} / \mathrm{mL}$; perlakuan $\mathrm{G}(500$ $\mathrm{mg} / \mathrm{L})$ yaitu $36 \times 10^{4} \mathrm{sel} / \mathrm{mL}$ dan perlakuan $\mathrm{H}(1000 \mathrm{mg} / \mathrm{L})$ yaitu $33 \times 10^{4} \mathrm{sel} / \mathrm{mL}$ (Gambar

Tabel 1. Kepadatan Harian Chlorella sp. pada Penelitian Pendahuluan ( $\times 10^{4} \mathrm{sel} / \mathrm{mL}$ )

\begin{tabular}{cccccccccc}
\hline Perlakuan Hari ke- & A & B & C & D & E & F & G & H & I \\
\hline 0 & 10 & 10 & 10 & 10 & 10 & 10 & 10 & 10 & 10 \\
1 & 27 & 23 & 25 & 28 & 50 & 66 & 23 & 21 & 24 \\
2 & 29 & 27 & 33 & 39 & 69 & 82 & 25 & 23 & 30 \\
3 & 32 & 39 & 45 & 51 & 85 & 102 & 27 & 23 & 36 \\
4 & 40 & 52 & 70 & 81 & 120 & 135 & 33 & 29 & 45 \\
5 & 42 & 75 & 93 & 111 & 145 & 162 & 36 & 33 & 63 \\
6 & 37 & 48 & 60 & 66 & 90 & 111 & 28 & 25 & 44 \\
7 & 23 & 25 & 24 & 27 & 60 & 70 & 21 & 15 & 24 \\
\hline
\end{tabular}

Keterangan :

A : Ekstrak Eucheuma sp. 0,001 mg/L

F : Ekstrak Eucheuma sp. $100 \mathrm{mg} / \mathrm{L}$

$B$ : Ekstrak Eucheuma sp. 0,01 mg/L

$\mathrm{G}$ : Ekstrak Eucheuma sp. $500 \mathrm{mg} / \mathrm{L}$

C : Ekstrak Eucheuma sp. 0,1 mg/L

D : Ekstrak Eucheuma sp. $1 \mathrm{mg} / \mathrm{L}$

$\mathrm{H}$ : Ekstrak Eucheuma sp. $1000 \mathrm{mg} / \mathrm{L}$

E : Ekstrak Eucheuma sp. $10 \mathrm{mg} / \mathrm{L}$

I : Ekstrak Eucheuma sp. 0 mg/L 


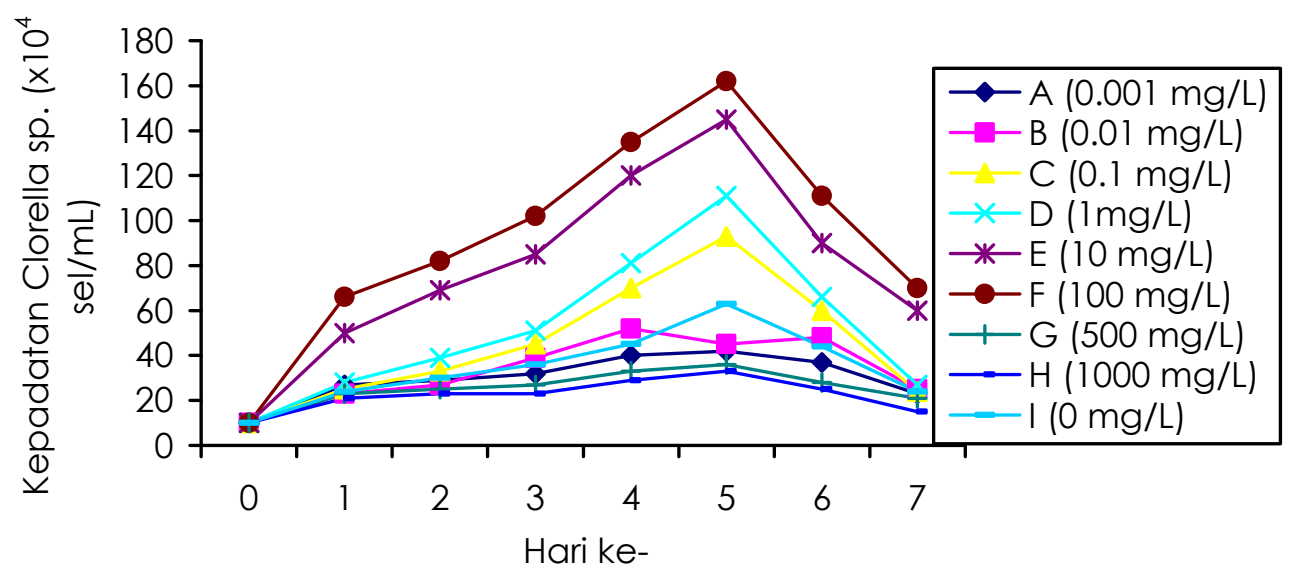

Gambar 1. Kepadatan Harian Chlorella sp pada penelitian pendahuluan

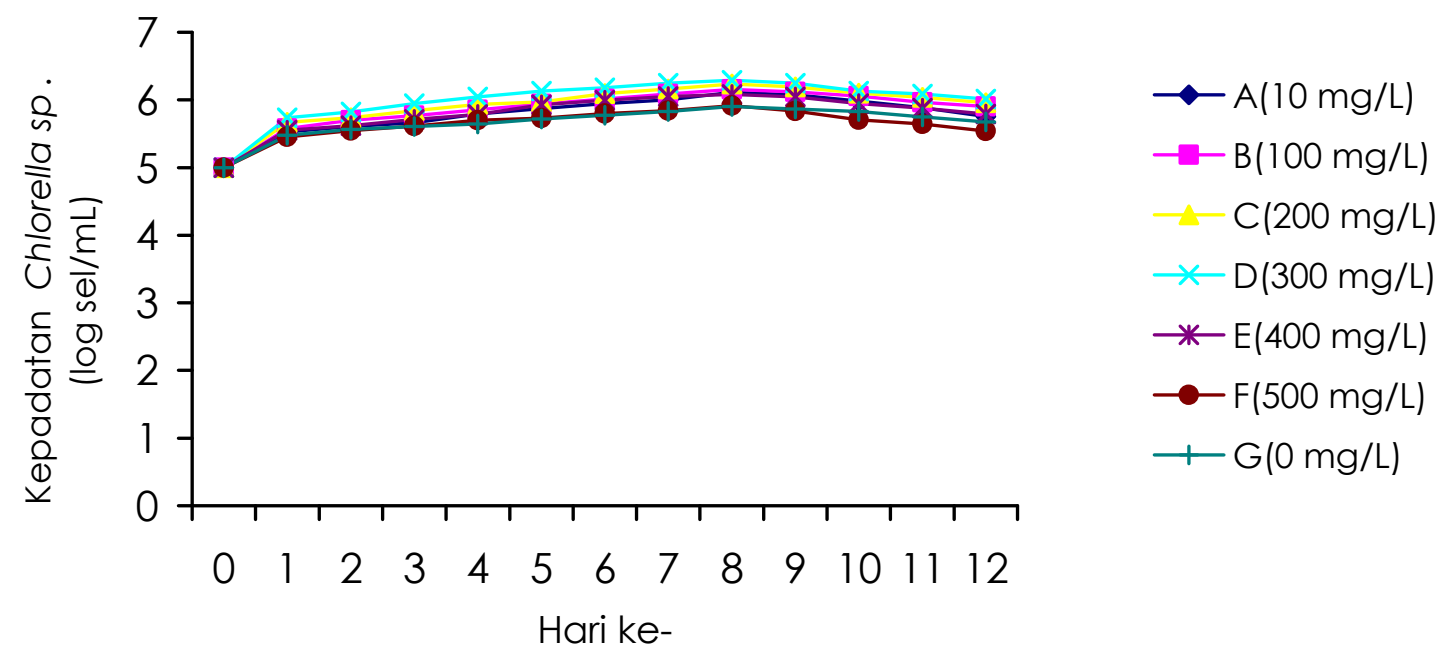

Gambar 2. Grafik Pertumbuhan Chlorella sp. pada Penelitian Utama

\section{Pertumbuhan Chlorella sp.}

Pada penelitian utama digunakan 7 perlakuan, yaitu A lekstrak Eucheuma sp. $10 \mathrm{mg} / \mathrm{L}$ ); B (ekstrak Eucheuma sp.100 $\mathrm{mg} / \mathrm{L}$ ); C (ekstrak Eucheuma sp. 200 $\mathrm{mg} / \mathrm{L}$ ); D (ekstrak Eucheuma sp. $300 \mathrm{mg} / \mathrm{L}$ ); E (ekstrak Eucheuma sp. $400 \mathrm{mg} / \mathrm{L}$ ); F (ekstrak Eucheuma sp. $500 \mathrm{mg} / \mathrm{L}$ ); G (tanpa pemberian ekstrak Eucheuma sp.).

\section{Kepadatan Chlorella sp. pada puncak populasi}

Kepadatan Chlorella sp. pada puncak populasi tertera pada Gambar 3. Kepadatan Chlorella sp. mencapai puncaknya pada hari ke- 8 dengan hasil dari yang tertinggi sampai terendah berturut-turut adalah perlakuan D (300 $\mathrm{mg} / \mathrm{L})=6,293$ log sel $/ \mathrm{mL} ;$ perlakuan $\mathrm{C}(200$ $\mathrm{mg} / \mathrm{L})=6,235 \mathrm{log} \mathrm{sel} / \mathrm{mL}$; perlakuan $B(100$ $\mathrm{mg} / \mathrm{L})=6,154 \mathrm{log} \mathrm{sel} / \mathrm{mL}$; perlakuan $\mathrm{A}(10$ $\mathrm{mg} / \mathrm{L})=6,111 \mathrm{log} \mathrm{sel} / \mathrm{mL}$; perlakuan E $(400$ $\mathrm{mg} / \mathrm{L})=6,079 \mathrm{log} \mathrm{sel} / \mathrm{mL}$ perlakuan $\mathrm{F}(500$ $\mathrm{mg} / \mathrm{L})=6,915 \mathrm{log} \mathrm{sel} / \mathrm{mL} ;$ perlakuan $\mathrm{G}$ (tanpa pemberian ekstrak Eucheuma sp) = 6,904 log sel /mL (Gambar 3).

Hasil pengujian data kepadatan Chlorella sp. pada puncak populasi dapat dilihat pada Lampiran 2, 3, 4, dan 5. Hasil uji normalitas dan homogenitas menunjukkan data menyebar normal dan homogen. Analisis ragam data kepadatan Chlorella sp. pada puncak populasi dapat dilihat pada Tabel 2.

Hasil analisis ragam data kepadatan Chlorella sp. pada puncak populasi 
menunjukkan bahwa pemberian ekstrak Eucheuma sp. memberikan perbedaan sangat nyata terhadap jumlah sel Chlorella sp. dengan hasil $F$ hitung lebih besar daripada $\mathrm{F}$ tabel pada taraf kepercayaan 99\%. Untuk mengetahui perbedaan antar perlakuan dapat dilihat dari Uji Ganda Duncan pada Tabel 3.

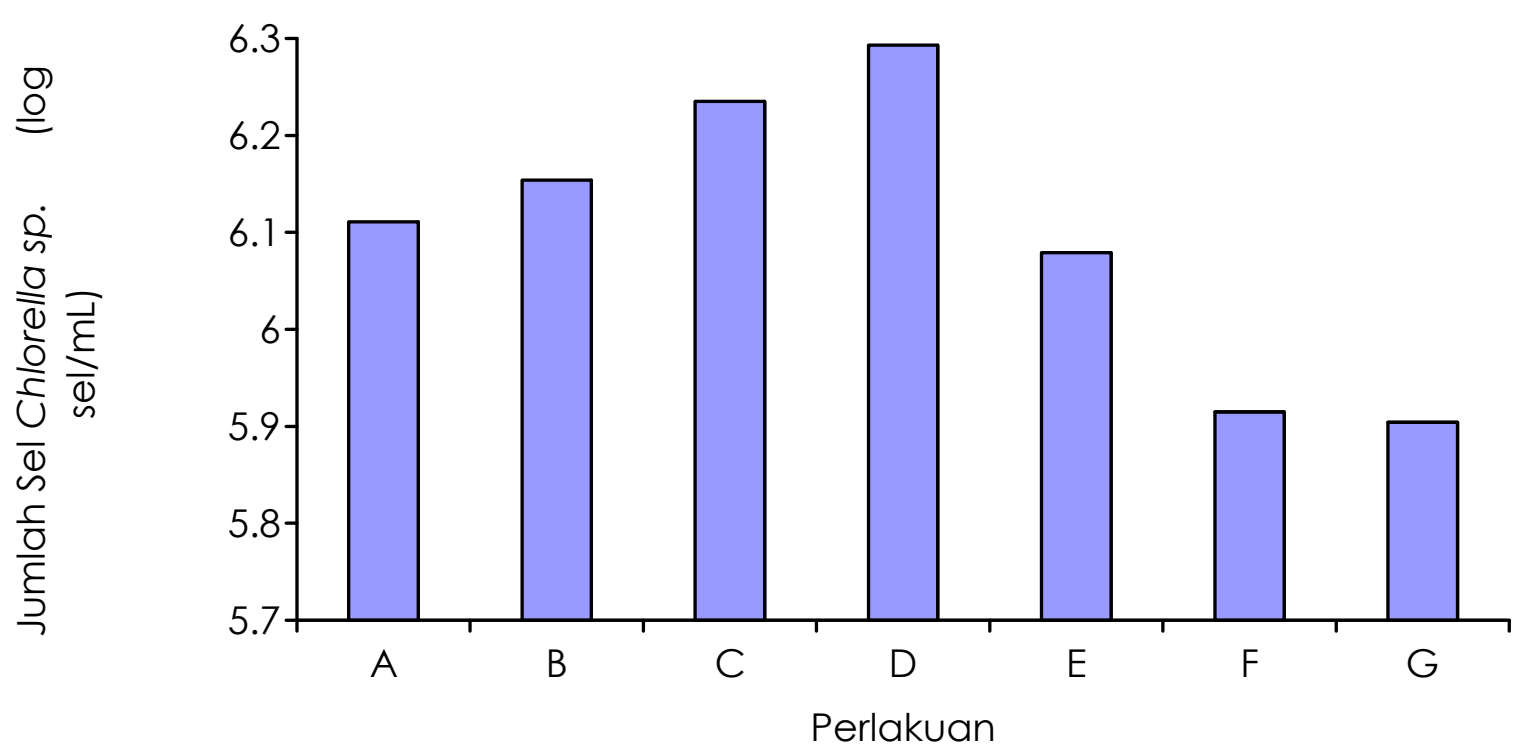

Gambar 3. Kepadatan Sel Chlorella sp Pada Puncak Populasi

Tabel 2. Analisis Ragam Data Kepadatan Chlorella sp. pada Puncak Populasi

\begin{tabular}{|c|c|c|c|c|c|c|}
\hline \multirow{2}{*}{ SK } & \multirow{2}{*}{$\mathrm{db}$} & \multirow{2}{*}{ JK } & \multirow{2}{*}{ KT } & \multirow{2}{*}{ Fhitung } & \multicolumn{2}{|c|}{ Ftabel } \\
\hline & & & & & 0.05 & 0.01 \\
\hline Perlakuan & 6 & 0.393989 & 0.0656648 & & 2.85 & 4.46 \\
\hline Galat & 14 & 0.017118 & 0.0012227 & $53.70415^{*}$ & & \\
\hline Jumlah & 20 & 0.411107 & 0.0668875 & & & \\
\hline
\end{tabular}

*F hitung $>$ F tabel $\rightarrow$ berbeda sangat nyata

Tabel 3. Uji Ganda Duncan Data Kepadatan Chlorella sp. pada Puncak Populasi

\begin{tabular}{|c|c|c|c|c|c|c|c|}
\hline Perlakuan & Nilai Tengah & & & Selisih & & & \\
\hline $\mathrm{D}$ & 6.2930 & $D$ & & & & & \\
\hline C & 6.2353 & 0.0577 & C & & & & \\
\hline B & 6.1543 & $0.1387^{* *}$ & 0.0810 & B & & & \\
\hline A & 6.1133 & $0.1797^{* *}$ & $0.1220^{* *}$ & 0.0410 & A & & \\
\hline$E$ & 6.0793 & $0.2137^{* *}$ & $0.1560^{* *}$ & 0.0750 & 0.0340 & $E$ & \\
\hline $\mathrm{F}$ & 5.9157 & $0.3773^{* *}$ & $0.3196^{* *}$ & $0.2386^{* *}$ & $0.1976^{* *}$ & $0.16360^{* *}$ & $\mathrm{~F}$ \\
\hline G & 5.9043 & $0.3887^{* *}$ & $0.3310^{* *}$ & $0.2500^{* *}$ & $0.2090^{* *}$ & $0.1750^{* *}$ & $0.01140 G$ \\
\hline
\end{tabular}


Kepadatan Chlorella sp. pada akhir populasi

Pada akhir populasi perlakuan D mempunyai jumlah sel yang paling tinggi dibandingkan perlakuan yang lain (Gambar 4).

Hasil analisis data kepadatan Chlorella sp. pada akhir menunjukkan data menyebar normal dan bersifat homogen
Analisis ragam data kepadatan Chlorella sp. pada akhir populasi terlihat pada Tabel 4.

Hasil analisis ragam menunjukkan perbedaan jumlah sel Chlorella sp. yang sangat nyata pada akhir populasi.

Perbedaan jumlah sel Chlorella sp. pada setiap perlakuan dapat dilihat pada uji Ganda Duncan

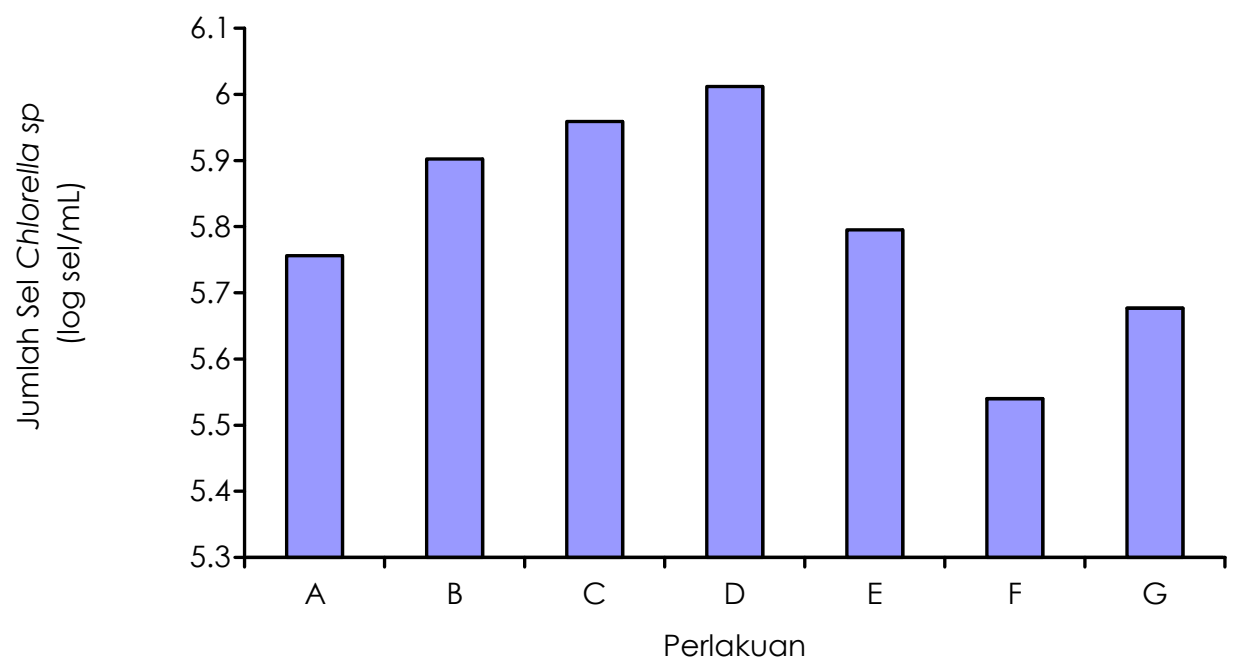

Gambar 4. Kepadatan Sel Chlorella sp pada Akhir Populasi

Tabel 4. Analisis Ragam Data Kepadatan Chlorella sp. pada Akhir Populasi

\begin{tabular}{|c|c|c|c|c|c|c|}
\hline \multirow{2}{*}{ SK } & \multirow{2}{*}{$\mathrm{db}$} & \multirow{2}{*}{ JK } & \multirow{2}{*}{ KT } & \multirow{2}{*}{ Fhitung } & \multicolumn{2}{|c|}{ Ftabel } \\
\hline & & & & & 0.05 & 0.01 \\
\hline Perlakuan & 6 & 0.495084 & 0.082514 & & 2.85 & 4.46 \\
\hline Galat & 14 & 0.060685 & 0.004335 & $19.03585^{*}$ & & \\
\hline Jumlah & 20 & 0.55577 & 0.086849 & & & \\
\hline
\end{tabular}

*F hitung $>$ F tabel $\rightarrow$ berbeda sangat nyata

Tabel 5. Uji Ganda Duncan Data Kepadatan Chlorella sp. pada Akhir Populasi

\begin{tabular}{cccccccc}
\hline Perlakuan & Nilai Tengah & \multicolumn{7}{c}{ Selisih } \\
\hline D & 6.0123 & D & & & & & \\
C & 5.9590 & 0.05330 & C & & & & \\
B & 5.9017 & 0.11060 & 0.0573 & B & & & \\
E & 5.7950 & $0.21730^{* *}$ & $0.1640^{* *}$ & 0.10670 & E & & \\
A & 5.7563 & $0.25600^{* *}$ & $0.2027^{* *}$ & 0.14540 & 0.03870 & A & \\
G & 5.6767 & $0.33560^{* *}$ & $0.2823^{* *}$ & $0.22500^{* *}$ & 0.11830 & 0.07960 & G \\
F & 5.5403 & $0.47200^{* *}$ & $0.4187^{* *}$ & $0.36140^{* *}$ & $0.25470^{* *}$ & $0.21600^{* *}$ & 0.13640 F \\
\hline
\end{tabular}

** = berbeda sangat nyata 



\section{Konstanta pertumbuhan spesifik Chlorella} sp.

Perlakuan D (300 mg/L) merupakan perlakuan yang menghasilkan kontanta pertumbuhan spesifik yang terbaik (Gambar 5). Data konstanta pertumbuhan spesifik menyebar normal dan bersifat homogen. Analisis ragam data konstanta pertumbuhan spesifik dapat dilihat pada Tabel 6.

Hasil analisis ragam menunjukkan konstanta pertumbuhan spesifik Chlorella sp. tidak memiliki perbedaan nyata antar perlakuan. Nilai konstanta pertumbuhan antar perlakuan tetap memiliki perbedaan, namun karena selisih nilainya kecil maka pada taraf kepercayaan $95 \%$ tidak terdapat perbedaan yang nyata antar perlakuan.

\section{Kualitas air}

Saat penelitian dilakukan pengukuran kualitas air dengan hasil yang dapat dilihat pada Tabel 7.

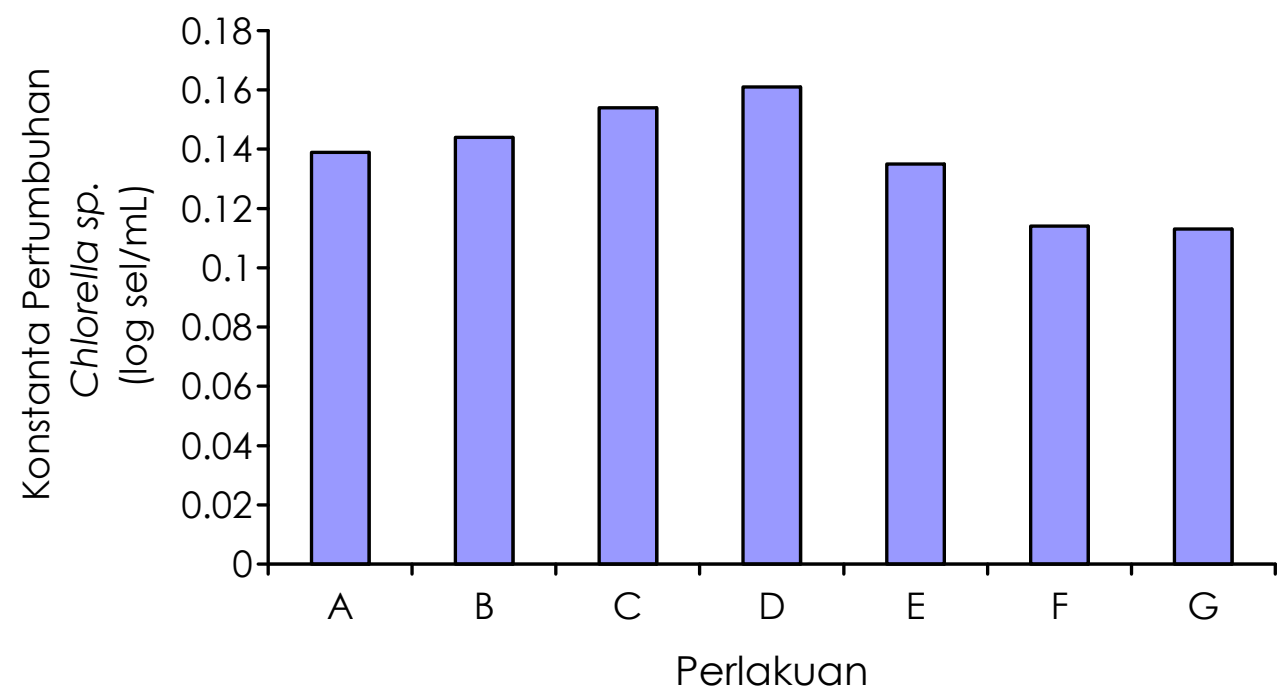

Gambar 5. Konstanta Pertumbuhan Spesifik Chlorella sp

Tabel 6. Analisis Ragam Data Konstanta Pertumbuhan Spesifik Chlorella sp.

\begin{tabular}{|c|c|c|c|c|c|c|}
\hline \multirow{2}{*}{ SK } & \multirow{2}{*}{$d b$} & \multirow{2}{*}{ JK } & \multirow{2}{*}{ KT } & \multirow{2}{*}{ Fhitung } & \multicolumn{2}{|c|}{ Ftabel } \\
\hline & & & & & 0.05 & 0.01 \\
\hline Perlakuan & 6 & 0.006081 & 0.001014 & & 2.85 & 4.46 \\
\hline Galat & 14 & 0.390259 & 0.027876 & 0.03636 & & \\
\hline Jumlah & 20 & 0.396341 & 0.028889 & & & \\
\hline
\end{tabular}

Tabel 7. Data Pengukuran Parameter Kualitas Air

\begin{tabular}{lcl}
\hline \multicolumn{1}{c}{ Parameter } & $\begin{array}{c}\text { Hasil } \\
\text { Pengukuran }\end{array}$ & \multicolumn{1}{c}{ Pustaka } \\
\hline Suhu $\left({ }^{\circ} \mathrm{C}\right)$ & $28-29$ & $25-35$ (Borowitzka dan Borowitzka, 1992) \\
Oksigen terlarut $(\mathrm{mg} / \mathrm{L})$ & $3,5-4$ & $1-5$ (Boyd, 1979) \\
Salinitas $(\% \circ)$ & 28 & $20-28$ (Borowitzka dan Borowitzka, 1992) \\
$\mathrm{pH}$ & 8 & $7,5-8,5$ (Taw, 1990) \\
\hline
\end{tabular}


Pada penelitian pendahuluan, puncak kepadatan Chlorella sp. terjadi pada hari ke-5, berbeda dengan penelitian utama yang mencapai puncaknya pada hari ke-8. Hal ini terjadi karena adanya perbedaan kemampuan Chlorella sp. dalam menyesuaikan diri dengan lingkungannya. Tingginya kepadatan sel Chlorella sp. pada hari ke-5 menyebabkan peningkatan kompetisi dalam memanfaatkan nutrien yang tersedia. Keterbatasan nutrien dan ruang gerak menyebabkan kepadatan sel Chlorella sp. mulai mengalaki penurunan sejak hari ke- 6.

\section{Pertumbuhan Chlorella sp.}

Hasil penelitian ini memperlihatkan bahwa pemberian ekstrak Eucheumasp. memberikan pengaruh positif terhadap kepadatan Chlorella sp. Hal ini dapat dilihat dari peningkatan jumlah sel yang signifikan dibanding dengan perlakuan yang tidak diberi ekstrak Eucheuma sp. (kontrol). Peningkatan kepadatan sel merupakan bagian dari pertumbuhan karena Salisbury and Ross (1992) menyatakan bahwa pertumbuhan berarti penambahan ukuran dalam bobot, volume, dan jumlah sel.

\section{Kepadatan Chlorella sp. pada puncak populasi}

Pada penelitian utama, semua perlakuan mencapai puncak kepadatan pada hari ke- 8. Hal ini didukung dengan kondisi media pemeliharaan yang baik. Perlakuan D (ekstrak Eucheuma sp. 300 $\mathrm{mg} / \mathrm{L})$ mempunyai kepadatan Chlorella sp. yang tertinggi yaitu 6,293 log sel $/ \mathrm{mL}$. Kepadatan tersebut lebih tinggi dibandingkan dengan perlakuan A (ekstrak Eucheuma sp. $10 \mathrm{mg} / \mathrm{L}$ ) sebesar 6,111 log $\mathrm{sel} / \mathrm{mL}$, perlakuan B (ekstrak Eucheuma sp.100 mg/L) sebesar 6,154 log sel/mL, perlakuan C (ekstrak Eucheuma sp.200 $\mathrm{mg} / \mathrm{L}$ ) sebesar 6,235 log sel/mL, perlakuan E (ekstrak Eucheuma sp. $400 \mathrm{mg} / \mathrm{L}$ ) sebesar 6,079 log sel/mL, perlakuan $\mathrm{F}$ (ekstrak Eucheuma sp.500 mg/L) sebesar 5,915 log sel $/ \mathrm{mL}$, dan perlakuan $G$ (tanpa pemberian ekstrak Eucheuma sp.) sebesar 5,904 log sel /mL. Hal ini menunjukkan perlakuan $\mathrm{D}$ memiliki media pemeliharaan yang lebih baik daripada perlakuan yang lain, dengan kualitas air yang memadai dan nutrien yang ada dapat dimanfaatkan dengan optimal.

Unsur - unsur pada ekstrak Eucheuma sp., yaitu natrium, kalium, kalsium, magnesium, fosfor, dan belerang terdapat jumlah yang optimal. Penambahan unsur unsur tersebut dapat meningkatkan kandungan nutrien media pemeliharaan sehingga memacu aktifitas enzim pada Chlorella sp., terutama untuk proses fotosintesis dan pembentukan protein. Kondisi ini mendukung pertumbuhan Chlorella sp. dapat mencapai titik tertinggi.

Selain memiliki kandungan unssur unsur yang dapat memacu pertumbuhan fitoplankton, ekstrak Eucheuma sp. juga berpotensi sebagai antibakteri. Peningkatan kepadatan Chlorella sp. terjadi karena pemberian ekstrak Eucheuma sp. yang mempunyai kemampuan sebagai antibakteri. Kemampuan sebagai antibakteri bermanfaat menyingkirkan mikroorganisme yang dapat menghambat pertumbuhan Chlorella sp. Dengan demikian pertumbuhan Chlorella sp. dapat berlangsung dengan maksimal (Anonymous, 2004).

\section{Kepadatan Chlorella sp. pada akhir populasi}

Setelah mencapai puncak pada hari ke- 8, kepadatan Chlorella sp. mengalami penurunan. Jumlah sel Chlorella sp. mulai mengalami penurunan sejak hari ke- 9 sampai hari ke- 12. Pada puncak populasi terjadi kompetisi dalam pemanfaatan nutrien dan ruang. Ada sel Chlorella sp. yang mampu bertahan tetapi ada juga yang kalah bersaing. Persaingan tersebut menyebabkan kematian sel Chlorella sp. sehingga terjadi penurunan jumlah sel Chlorella sp. pada akhir populasi.

\section{Konstanta pertumbuhan spesifik Chlorella} sp.

Semua perlakuan pada penelitian utama dengan pemberian ekstrak 
Eucheuma sp. antara $10 \mathrm{mg} / \mathrm{L}$ sampai 500 $\mathrm{mg} / \mathrm{L}$ menghasilkan kepadatan Chlorella sp. yang lebih tinggi daripada kepadatan awal sebesar $100.000 \mathrm{sel} / \mathrm{mL}$. Selisih antara jumlah sel pada puncak populasi dan jumlah sel pada awal populasi menghasilkan nilai konstanta pertumbuhan spesifik.

Konstanta pertumbuhan spesifik Chlorella sp. pada perlakuan A lekstrak Eucheuma sp.10 mg/L) sebesar 0,139. Nilai tersebut semakin meningkat pada perlakuan B (ekstrak Eucheuma sp. 100 $\mathrm{mg} / \mathrm{L})$ sebesar 0,144 dan perlakuan $C$ (ekstrak Eucheuma sp. 200 mg/L) sebesar 0,154 . Konstanta pertumbuhan spesifik terbaik terjadi pada perlakuan D (ekstrak Eucheuma sp. $300 \mathrm{mg} / \mathrm{L}$ ) yaitu sebesar 0,161 . Diduga bahwa pemberian ekstrak Eucheuma sp. sebesar $300 \mathrm{mg} / \mathrm{L}$ dapat menekan bakteri dan mikroorganisme patogen yang dapat menghambat pertumbuhan Chlorella sp.

Ekstrak Eucheuma sp. melepaskan karaginan ke dalam air media yang selanjutnya dapat menghancurkan bakteri dengan cara mempengaruhi dinding sel kemudian masuk ke dalam inti sel bakteri dan mikroorganisme. Hal inilah dapat menghambat pertumbuhan bakteri dan mikroorganisme patogen (Prentis, 2000).

Konstanta pertumbuhan spesifik pada perlakuan E (ekstrak Eucheuma sp. $400 \mathrm{mg} / \mathrm{L}$ ) adalah 0,135 dan perlakuan $\mathrm{F}$ (ekstrak Eucheuma sp. $500 \mathrm{mg} / \mathrm{L}$ ) sebesar 0,114 . Data ini menunjukkan penurunan apabila dibandingkan dengan perlakuan D (ekstrak Eucheuma sp. $300 \mathrm{mg} / \mathrm{L}$ ). Perlakuan $G$ (tanpa pemberian ekstrak Eucheuma sp.) konstanta pertumbuhan spesifik sebesar 0,113 yang berarti lebih tinggi daripada perlakuan $\mathrm{F}$ ( pemberian ekstrak Eucheuma sp. $500 \mathrm{mg} / \mathrm{L})$. Hal ini terjadi karena Chlorella sp. memerlukan adaptasi pada media yang telah diberi ekstrak Eucheuma sp. dengan konsentrasi yang tinggi. Diduga terjadi kelebihan kandungan mineral pada media pemeliharaan pada perlakuan $F$ dan $G$, dimana kondisi tersebut berpotensi menimbulkan dominasi organisme lain (Fox, 1987).

\section{Kualitas air}

Kualitas air media harus senantiasa dikontrol karena menurut Laode (1991) berbagai faktor, baik yang bersifat internal (jenis dan umur) maupun yang bersifat eksternal (suhu, salinitas, $\mathrm{pH}$ air, intensitas cahaya, ruang, waktu serta cara penanganan) dapat mempengaruhi pertumbuhan fitoplankton.

Lobban and Wynee (1985) menyatakan suhu akan mempengaruhi tingkat difusi dan metabolisme sel. Kenaikan suhu menyebabkan metabolisme berjalan lebih cepat. Pada pengukuran selama penelitian didapatkan kisaran suhu antara $28^{\circ} \mathrm{C}-29^{\circ} \mathrm{C}$. Kisaran tersebut sangat baik bagi Chlorella sp., dimana suhu optimum untuk pertumbuhannya antara $25^{\circ} \mathrm{C}-35^{\circ} \mathrm{C}$ dengan suhu maksimal $37^{\circ} \mathrm{C}$ (Borowitzka and Borowitzka, 1992).

Penentuan salinitas berfungsi untuk menciptakan kondisi lingkungan yang mendukung proses metabolisme dan tekanan osmotik. Menurut Borowitzka and Borowitzka (1992) salinitas yang optimal bagi pertumbuhan Chlorella sp. adalah antara 20\% $-28 \%$. Salinitas yang digunakan pada penelitian ini adalah $28 \%$ sehingga layak bagi pertumbuhan Chlorella sp.

Menurut Baldwin and Mandelsshon (2004) peningkatan kepadatan Chlorella sp. tergantung pada kadar oksigen terlarut pada media pemeliharaan. Kisaran oksigen terlarut pada penelitian adalah antara 3,5 mg/L $-4 \mathrm{mg} / \mathrm{L}$. Kisaran tersebut layak bagi pertumbuhan Chlorella sp. karena Boyd (1979) menyatakan kadar oksigen terlarut yang baik untuk pertumbuhan Chlorella sp. antara $1 \mathrm{mg} / \mathrm{L} \mathrm{-}$ $5 \mathrm{mg} / \mathrm{L}$.

Air yang mempunyai pH antara 7,5 8,5 mendukung kehidupan fitoplankton. Pada umumnya dalam jangkauan $\mathrm{pH}$ itu pertumbuhan fitoplankton tidak terganggu. (Taw, 1990). $\mathrm{pH}$ yang didapatkan pada penelitian ini adalah 8. Dengan demikian $\mathrm{pH}$ tersebut masih layak bagi perkembangan fitoplankton, dalam hal ini Chlorella sp. 


\section{KESIMPULAN}

Dari penelitian mengenai pengaruh ekstrak Eucheuma sp. terhadap kepadatan Chlorella sp. ini dapat diambil kesimpulan, Ekstrak Eucheuma sp. dengan berbagai konsentrasi memberikan kepadatan sel Chlorella sp. yang berbeda.

Kepadatan sel Chlorella sp. cenderung mengalami peningkatan mulai dari perlakuan A lekstrak Eucheuma sp. 10 $\mathrm{mg} / \mathrm{L}$ ), perlakuan B (ekstrak Eucheuma sp. $100 \mathrm{mg} / \mathrm{L}$ ), perlakuan C (ekstrak Eucheuma sp. $200 \mathrm{mg} / \mathrm{L}$ ) hingga perlakuan D (ekstrak Eucheuma sp. $300 \mathrm{mg} / \mathrm{L})$. Perlakuan D (ekstrak Eucheuma sp. 300 mg/L) menghasilkan kepadatan sel Chlorella sp. yang tertinggi pada puncak populasi $(6,923 \mathrm{log} \mathrm{sel} / \mathrm{mL})$ dan akhir populasi $(6,012$ log sel $/ \mathrm{mL}$ ) dengan konstanta pertumbuhan spesifik Chlorella sp. sebesar 0,161 .

\section{DAFTAR PUSTAKA}

Adiwijaya dan Raharjo. 1998. Pengaruh Penggunaan Nutrilake Terhadap Pertum buhan Udang Pada Budidaya Sistem Semi Intensif. Direktorat Jenderal Perikanan Balai Budidaya Air Payau. Jepara. $46 \mathrm{hlm}$.

Arikunto, S. 1998. Prosedur Penelitian. Rineka Cipta. Jakarta. $378 \mathrm{hlm}$.

Anonymous. 2004. Algae-Kelp-Seaweed for Industrial, Nutritional, and Agricultural Use. http://www.algae@safariseeds. com. 4 pp.

Borowitzka, M and Borowitzka, L. 1992. Microalgae Biotechnology. Cambridge University Press. 168 pp.

Baldwin, A.H. and Mandelsshon ,I.A,. 2004. The Effect of Salinity Level on the

Photosynthetic. Aquatic Botany. 4 pp.

Ekasari, N. L. 2004. Uji Potensi Antibakteri Beberapa Ekstrak Rumput Laut Yang Terdapat Di Pantai Bandengan
Jepara. Fakultas Perikanan dan Ilmu Kelautan, Universitas Diponegoro. Semarang. $68 \mathrm{hlm}$.

Fox, J.M. 1987. Teknik Budidaya Intensif Dalam Teknologi Pembenihan Udang. Gajah Mada University Press. Yogyakarta (Diterjemahkan oleh Gajah Mada University Press). $52 \mathrm{hlm}$.

Isnansetyo, A. dan Kurniastuty. 1995. Teknik Kultur Phitoplankton dan Zooplankton. Kanisius. Yogyakarta. $116 \mathrm{hlm}$.

Mujiman, A. 2000. Makanan Ikan. Penebar Swadaya. Jakarta. $190 \mathrm{hlm}$.

Laode, M.A. 1991. Budidaya Rumput Laut. Kanisius. Jakarta. $128 \mathrm{hlm}$.

Lobban, J.C. and Wynee, M.J. 1985. The Biology of The Seaweeds. Blackwell Science Publication. London.

Prentis, S. 2000. Bioteknologi. Erlangga. Jakarta. $135 \mathrm{hlm}$.

Taw, N. 1990. Petunjuk Pemeliharaan Kultur Murni dan Massal Mikroalga. Proyek Pengembangan Budidaya Udang. Jepara (Diterjemahkan oleh B. Martosudarmo dan I. Wulani). $30 \mathrm{hlm}$.

Srigandono, B. 1989. Rancangan Percobaan. Fakultas Peternakan, Universitas Diponegoro. Semarang. 100 hlm.

Salisbury and Ross. 1992. Fisiology Tumbuhan. Penerbit Institut Teknologi Bandung. Bandung.

Sosiawan, T. G. 2004. Pengeruh Berbagai Tingkat Konsentrasi Kaporit Terhadap Pertumbuhan Kuantitatif Chlorella sp. Universitas Diponegoro, Semarang. 58 hlm.

Sudjana. 1986. Desain dan Analisa Eksperimen. Tarsito. Bandung. $474 \mathrm{hlm}$.

Sachlan, M. 1984. Planktonologi. Fakultas Peternakan dan Perikanan. Universitas Diponegoro. Semarang. $117 \mathrm{hlm}$.

Winarno, F.G. 1990. Teknologi Pengolahan Rumput Laut. Pustaka Sinar Harapan. Jakarta. $101 \mathrm{hlm}$.

Wahyuni, S. 1988. Laporan Kegiatan Training Alga UNDP-FAO. Balai Budidaya Air Payau. Jepara. $17 \mathrm{hlm}$. 